\title{
IMPLEMENTASI NILAI-NILAI PANCASILA DALAM LINGKUNGAN KELUARGA
}

\author{
Rizal Saputra ${ }^{1}$, Ajat Rukajat ${ }^{2}$, Yayat Herdiana ${ }^{3}$ \\ ${ }^{1}$ Universitas Singaperbangsa Karawang \\ ${ }^{3}$ Universitas Singaperbangsa Karawang \\ 2 Universitas Singaperbangsa Karawang
}

\begin{abstract}
E-mail: Rizalsaputra17onk@gmail.com¹, Ajatrukajat613@gmail.com², yayatherdiana19@gmail.com
\end{abstract}

\begin{tabular}{|l|l|l|}
\hline Receive: 13/07/2021 & Accepted: 23/09/2021 & Published: 01/10/2021 \\
\hline
\end{tabular}

\begin{abstract}
Abstrak
Penelitian ini dilatarbelakangi dengan beragam problematika yang terjadi pada masyarakat Indonesia. Mengikisnya nilai-nilai karakter didalam masyarakat menjadi sebuah kekhawatiran dan menjadi tugas kita bersama untuk menanggulanginya, terutama pada bidang pendidikan. Dekadensi moral tidak hanya terjadi pada generasi muda saja, tetapi juga terjadi pada tingkat elit politisi yang memegang jabatan, rusaknya moral ditandai dengan maraknya kasus korupsi, kolusi dan nepotisme. Serta pada tingkat masyarakat dengan meningkatnya kejahatan, narkoba, pencabulan anak dibawah umur dan sebagainya. Terlebih pada tingkat remaja yang dibenturkan dengan bebasnya dunia digital banyak anak-anak remaja yang tersandung kasus seksual dibawah umur, bullying, tauran, dan berbicara kotor dimuka umum. Hal demikian setiap harinya seakan sudah menjadi sebuah kebisaan yang terjadi dimasyarakat. Menghidupkan kembali nilai-nilai pancasila didalam masyarakt terutama didalam keluarga adalah upaya pencegahan terhadap problematika yang terjadi sekarang. Pendidikan Pacasila adalah pendidikan nilai-nilai yang bertujuan membentuk sikap dan prilaku positif manusia sesuai dengan nilai-nilai yang terkandung dalam pancasila. Tujuan penelitian ini adalah untu mengetahui sejauh mana pendidikan pancasila yang diajarkan didalam keluarga. Metode penelitian ini menggunakan metode kualitatif deskriptif. Dengan menggunakan teknik pengumpulan data berupa dokumentasi, observasi dan wawancara. Hasil penelitian yang dilakukan kepada keluarga bapak Adem dan Ibu Uun menunjukan bahwa dalam mengempelentasiaanya nilai-nilai pancasila yaitu dengan keteladaan baik dalam urusan agama, mengambil keputusan secara bersama, mengasihi tanpa dibeda-bedakan serta dalam mengambil keputusan anggota keluarga selalu mengadakan musyawarah bersama untuk mencapai kemufakatan. Serta berbuat baik kepada lingkungan sekitar.
\end{abstract}

Kata kunci: Dekadensi Moral, Nilai Pendidikan Pancasila

\section{Abstract}

This research is motivated by various problems that occur in Indonesian society. The erosion of character values in society is a concern and it is our collective duty to overcome them, especially in the field of education. Moral decadence does not only occur in the younger generation, but also occurs at the elite level of politicians who hold office, moral damage is marked by rampant cases of 
Jurnal Edumaspul, 5 (2), Year 2021 - 396

Rizal Saputra', Ajat Rukajat' ${ }^{2}$, Yayat Herdiana ${ }^{3}$

corruption, collusion and nepotism. And at the community level with increasing crime, drugs, sexual abuse of minors and so on. Especially at the youth level, which is collided with the freedom of the digital world, there are many teenagers who stumble over cases of underage sexuality, bullying, bullying, and speaking dirty in public. This every day seems to have become a habit that occurs in the community. Reviving Pancasila values in society, especially in the family, is an effort to prevent the problems that are happening now. Pancasila education is values education that aims to shape positive human attitudes and behavior in accordance with the values contained in Pancasila. The purpose of this study was to find out the extent to which Pancasila education was taught in the family. This research method uses descriptive qualitative method. By using data collection techniques in the form of documentation, observation and interviews. The results of research conducted on the families of Mr. Adem and Mrs. Uun showed that in implementing Pancasila values, namely by good example in religious matters, making decisions together, loving without discrimination and in making decisions, family members always hold joint deliberation to reach consensus. And do good to the environment.

\section{Keywords: Moral Decadence, Pancasila Education Values}

\section{Pendahuluan}

Dalam rangka mencapai tujuan pendidikan yaitu "mencerdaskan kehidupan bangsa", dalam UU no 20 tahun 2003 tentang sistem pendidikan nasional mempunyai fungsi untuk mengembangkan kemampuan dan membentuk watak serta peradaban bangsa yang bermartabat dalam rangka mencerdasakan kehidupan bangsa dan tujuannya untuk mengembangkan potensi peserta didik agar menjadi manusia yang beriman dan bertakwa kepada Tuhan Yang Maha Esa, berakhlak mulia, sehat, berilmu, cakap, kreatif, madiri dan menjadi warga negara yang demokratis serta bertanggung jawab. Maka pendidikan tidak akan terlepas dari ajaran pancasila sebagai dasar penyelenggaran pendidikan di indonesia.

Pendidikan merupakan upaya untuk membentuk kepribadian peserta didik baik secara lahir maupun batin agar menjadi manusia yang benar-benar manusia seutuhnya. Pendidikan adalah wadah atau tempat dalam proses pendewasaan dan pembentukan karakter seriap individu manusia manusia (Djumali 2018 :111)

Secara ideologis pembangunan karakter bangsa merupakan upaya mengejawantahkan ideologi pancasila dalam kehidupan berbangsa dan bernegara dalam pengertian membumikan ideologi kedalampraksis kehidupan masyarakat maupun ketatanegaraa (Dasim Budimansyah $2011: 53)$

Pancasila adalah pilar ideologis negara indonesia. Terdiri dari dua kata sanskerta, Panca berarti lima dan Sila berarti prinsip atau asas. Pancasila merupakan rumusan dan pedoman kehidupan berbangsa dan bernegara bagi seluruh rakyat indonesia. (wikipedia diaksess pada 28 juli 2021)

Pancasila merupakan dasar sekaligus ideologi bangsa dan negara indonesia, mengajarkan prinsip kehidupan, berbangsa, dan bernegara. Pancasila yang terdapat pada pembukaan UUD 1945 diuraikan lebih mendalam pada pasal-pasal yang berbunyi : nilai-nilai pancasila menjadi nilai yang mengatur seluruh kehidupan bebangsa dan bernegara dari bidang pendidikan, hukum, politik, ekonomi, budaya, dan kemasyarakatan. Pendidikan budaya dan karakter bangsa memiliki tujuan untuk mempersiapkan generasi bangsa yang baik, yaitu bangsa yang berkemampuan, berkemauan seta mengimplementasikan nilai-nilai pancasila dalam kehidupan sebagai bangsa indonesia (Sri Juliani 2010. Jurnal Pendidikan Dan Kebudayaan).

Pancasila memiliki kedudukan dan fungsi bagi Negara Kesatuan Republik Indonesia yaitu. 1). Pancasila sebagai jiwa bangsa Indonesia : sebagai nilai-nilai kehidupan dalam masyarakat bangsa indonesia melalui penjabaran instrumental sebagai ancuan hidup serta sesuai dengana napas jiwa bangsa indoneisa dan karna pancasila lahir bersama dengan lahirnya bangsa indonesia.

2). Pancasila sebagai kepribadian bangsa Indonesia : merupakan bentuk peran dalam menunjukan adanya kepribadian bangsa 
Jurnal Edumaspul, 5 (2), Year 2021 - 397 Rizal Saputra ${ }^{1}$, Ajat Rukajat ${ }^{2}$, Yayat Herdiana ${ }^{3}$

indonesia yang dapat dibedakan dengan bangsa lain, yaitu sikap mental, tingkah laku, dan amal perbuatan bangsa indonesia.

3). Pancasila sebagai pandangan hidup bangsa Indonesia : merupakan kristalisasi pengalaman hidup dalam sejarah bangsa indonesia yang telah membentuk sikap, watak, prilaku, tata nilai norma, dan etika yang telah melahirkan pandangan hidup.

4). Pancasila sebagai dasar negara Indonesia : untuk mengatur tatanan kehidupan bangsa Indonesia dan negara Indonesia yang mengatur semua pelaksanaan sistem ketatanegaraan Indonesia sesuai Pancasila.

5). Pancasila sebagai sumber dari segala sumber hukum bagi negara republik Indonesia : sebagai segala sumber hukum di negara Indonesia karena segala kehidupan negara Indonesia berdasarkan pancasila, itu juga harus berlandaskan hukum. Semua tindakan kekuasaan dalam masyarakat harus berlandaskan hukum.

6). Pancasila sebagai perjanjian luhur bangsa Indonesia pada waktu mendirikan negara : karena pada waktu mendirikan negara pancasila adalah perjanjian luhur yang disepakati oleh para pendiri negara untuk dilaksanakan, pelihara, dan dilestarikan.

7). Pancasila sebagai cita-cita dan tujuan bangsa Indonesia : karena dalam pancasila, mengandung cita-cita dan tujuan negara Indonesia adalah menjadikan pancasila sebagai patikan atau landasan pemersatu bangsa.

Pendidikan pacasila adalah pendidikan nilai-nilai yang bertujuan membentuk sikap dan prilaku positif manusia sesuai dengan nilai-nilai yang terkandung dalam pancasila (Kaelan 2010:29) anak muda indonesia adalah aset penting bagi negara, dimana nantinya anak mudalah yang akan menjadi penerus pendiri bangsa yang akan menjadi pemimpin yang membawa indonesia menjadi negara yang maju dan unggul. Pendidikan pancasila sebagai pondasi untuk membentengi karakter anak bangsa akan menunjang sosok pribadi manusia yang cinta akan tanah airnya dan rela berkorban demi negara dan bangsanya. Sebabb tujuan dari pendidikan pancasila ini adalah untuk menghidupkan rasa cinta tanah air (nasionalis), mengembangkan kepekaan jati diri dan moral sosial bangsa dalam kehidupan yang sesuai dengan nilai-nilai yang terkandung dalam pancasila.
Pendidikan karakter sebagai integral dari keseluruhan tatanan sistem pendiikan nasional, maka harus dikembangkan dan dilaksanakan secara sistematik dan holistik dalam tiga pilar pendidikan nasional, yaitu satuan pendidikan (sekolah, perguruan tinggi, satuan/ program pendidikan nonformal), keluarga (keluarga inti, keluarga luas, keluarga orang tua tunggal), dan Masyarakat (koomunitas, masyarakat lokal, wilayah, bangsa dan negara). Hal ini konsisten dengan konsep tanggung jawab pendidikan nasional yang berada pada sekolah, keluarga, dan masyarakat.

Dewasa ini, pendidikan karakter merupakan sebuah pendidikan yang sangat efektif dalam meminimalisir dekadensi moral yang terjadi di indonesia. Krisis moral menjadi masalah utama yang harus segera ditindak lanjuti di dalam pendidikan, keluarga, dan masyarakat. sebab karakter bangsa tercermin dari masyarakatnya.

Dekadensi moral tidak hanya terjadi pada generasi muda saja, tetapi juga terjadi pada tingkat elit politisi yang memegang jabatan, rusaknya moral ditandai dengan maraknya kasus korupsi, kolusi dan nepotisme. Serta pada tingkat masyarakat dengan meningkatnya kejahatan, narkoba, pencabulan anak dibawah umur dan sebagainya. Terlebih pada tingkat remaja yang dibenturkan dengan bebasnya dunia digital banyak anak-anak remaja yang tersandung kasus seksual dibawah umur, bullying, tauran, dan berbicara kotor dimuka umum. Hal demikian setiap harinya seakan sudah menjadi sebuah kebisaan yang terjadi dimasyarakat.

Zaman yang telah bertransformasi menjadi sebuah era digitalisasi yang mudah, bebas, terbuka dan dapat diakses dengan semua kalangan masyarakat. Tentunya diperlukan sebuah tatanan nilai yang baik. Salah satunya dengan menerapkan pendidikan pancasila sebagai karakter bangsa didalam keluarga.

Keluarga sebagai miniatur negara merupakan tempat berlangsungnya proses pendidikan yang pertama dan paling utama bagi anak-anak yang akan memulai tumbuh kembang menjadi dewasa. Kenapa dikatakan demikian ?. sebab didalam keluarga, anak pertama kali mendapatkan bimbingan secara langsung dari orangtuanya dan didalam keluarga juga anak mengenal dan berinteraksi lansung dengan lingkungannya. Dan juga didalam keluarga anak 
akan di ajarkan bagaimana dia menjadi seorang anak yang taat kepada agamanya dan patuh kepada orangtuanya (Siti Makhmudah 2018 : 271)

Keluarga mempunyai peran penting dalam mengembangkan karakter anak bangsa, sebab keluarga merupakan pusat pendidikan yang pertama kali anak belajar tentang situasi dan prilaku. Anak yang dibesarkan dilingkungan keluarga yang terdidik pasti berbeda dengan anak yang dibesarkan di keluarga yang tidak terdidik, justru itulah pentinganya sebagai orang tua harus mengerti dan paham konsep pendidikan pertama di dalam keluarga kepada anak sehingga nantinya akan menjadi peluang besar untuk bertumbuh kembang dengan baik anak tersebut.

Orang tua sebagai pendidik pertama dan paling utama, berkepentingan langsung dalam mengupayakan membina perkembangan anak dari kecil ke dewasa, terutamanya ketika anak berada pada perkembangan dan pertumbuhan. Selain ituorantua juga mempunyai lewajiban menumbuhkan anak atas dasar pemahaman dan dasar- dasar pendidikan agama sejak masa perkembangannya. Orang tua hendaknya harus memiliki strategi dalam menjadi perannya menerapkan pola asuh danpola pendidikannya secara lebih tepat. Dalam hal ini konsep orang tua dalam keluarga bukan hanya orang yang melahirkan seorang anak, melainkan juga orang yang mengasuh, melindungi, menafkahi dan memberikan kasih sayang kepada anak, maka dari itu dapat di katakan bahwa orang tua adalah guru perama dan paling utama, pelindung utama, sumber kehidupan anak, tempat bergantung bagi anak, dan sumber kebagagiaan bagi anak (Hibana S. Rahman 2010 : 96-99)

berdasarkan uraian diatas peneliti tertarik untuk melakukan penelitian mengenai implementasi nilai-nilai pancasila di lingkungan keluarga.

\section{METODE PENELITIAN}

Tujuan dari penelitian ini yaitu untuk mendeskripsikan situasi pendidikan/penerapan karakter nilai-nilai pacasila dilingkungan keluarga. Penelitian ini menggunakan jenis penelitian kualitatif deskriftif. Menurut M. Najir (1998) menyatakan metode deskriptif adalah metode penelitian yang mengambarkan dan menjabarkan seluruh fenomena yang terjadi sekarang dengan menggunakan prosedur ilmiah untuk bisa menjawab setiap masalah secara aktual. Selain itu penelitian deskriptif juga merupakan cara tepat untuk menerangkan makna secara sistematis dari fakta, frasa ataupun kalimat dari suatu bahasa yang kemudian di kelompokan menurut pola tertentu dan makna yang di hasilkan, selanjutnya dianalisis. Dengan demikian penelitian ini adalah penelitian yang tidak menghasilkan angka-angka, tetapi menghasilkan data deskriptif yang berupa ucapan, prilaku dari subjek yang diteliti dalam mengimplementasikan nilai-nilai pancasila dalam lingkungan keluarga.

Sumber data dalam penelitian ini menggunakan dua sumber data yang akan memberikan informasi langsung kepada peneliti yaitu sumber data primer dan skunder. Sumber data primer dalam penelitian ini adalah didapatkan langsung dari anggota keluarga Bapak Adem dan Ibu Uun salah satu anggota keluarga yang terletak di Kampung Cisarua, Desa Sirnajati, Kecamatan Cibarusah, Kabupaten Bekasi. Dari sumber data tersebut peneliti menggali informasi yang berkaitan dengan proses pendidikan dalam menanamkan nilai-nilai pancasila di lingkungan keluarga. Kemudian sumber data skunder dalam penilitian ini adalah sumber data yang tidak langsung, yaitu sumber data yang diperoleh atau dikumpulkan oleh orang yang melakukan penelitian maupun teoriteori parah ahli. Data ini biasanya diperoleh dari perpustakaan maupun secara digital yang memberikan data kepada pengumpul data baik berupa, buku-buku, undang-undang, jurnal, majalah, makalah, artikel, dan karya ilmiah lain sebagainya yang relevan dengan penelitian tentang nilai-nilai pancasila didalam keluarga.

Untuk mengumpulkan data, peneliti menggunakan teknik observasi, wawancara, dan dokumentasi. Dalam menganalisis data, peneliti menggunakan model Miles and Huberman (Sugiono 2013:246-253) menyatakan bahwa aktivitas dalam analisis data kualitatif dilakukan secara interaktif dan berlangsung secara terus menerus sampai tuntas, sehingga datanya sudah jenuh. Aktivitas dalam menganalisis data menurut model Miles and Huberman adalah data reductions, data display, verifcation. mereduksi data berarti merangkum, memilih halhal yang pokok. Memfokuskan pada hal-hal yang penting, dengan demikian data yang telah 
direduksi akan memberikan gambaran yang lebih jelas am mempermudah peneliti untuk melakukan pengumpulan data mengenai pengimplementasian nilai-nilai pancasila dalam lingkugan keluarga. Setelah data direduksi, maka langkah selanjutnya yaitu menyajikan data yaitu merangkai beberapa data dalam suatu informasi berbentuk uraian mengenai nilai-nilai pancasila, dengan mendisplay data maka akan memudahkan untuk memahami apa yang terjadi, dan menyimpulkan. Langkah ke tiga yaitu penarikan kesimpulan yang dilakukan peniliti yaitu mengumpulkan bukti penelitian lapangan. Selanjutnya peneliti melakukan deskripsi dari data yang diperoleh dan di analisis secara cermat dan terstruktur.

\section{Hasil dan Pembahasan}

Hasil penelitian berkaitan dengan impelementasi nilai-nilai pancasila dilingkungan keluarga adalah diambil dari hasil dokumentasi, observasi, dan wawancara. Implementasi nilainilai pancasila pada anak di lingkungan keluarga sangat penting sekali untuk ditanamkam dan diterapkan didalam kesehariannya. Sebab keluarga adalah pendidikan pertama bagi seorang anak untuk belajar, berkembang dan memahami lingkungan nya. Keluarga yang berhasil dalam menanamkan karakter kepada anaknya terlebih penanaman karakter yang terdapat pada nilai-nilai pancasila adalah keluarga yang hebar, yang akan menjadikan anaknya sebagai manusia yang mempunyai moral sosial dan cinta tanah airnya.

Pada nilai pancasila ke-1 Ketuhanan Yang Maha Esa didalam keluarga menjelaskan bahwa dalam agama Islam bahwa Ketuhanan Yang Maha Esa adalah bentuk keimanan kita yang harus senantiasa kita pegang dan kita ajarkan kepada keturunan kita, karna tauhid inilah yang akan menjadi pondasi serta landasan kita dalam berkehidupan terlebih di dalam keluargadan betetangga yang berbeda agamanya. Menurut bapak Adem Tuturnya "Ketuhanan Yang Maha Esa itu dalam Islam adalah Allah SWT. adalah tuhan yang maha tunggal. Artinya bahwa saya selaku orang tua wajib mengajarkan kepada anak saya mengenai ketauhidan, sebab itu upaya dalam menjaga pondasi keimanan dalam berlslam, mengajak anak beribadah tepat waktu dan menghormati perbedaan adalah bentuk kita taat kepada agama yang kita yakini". Dan Ibu
Uun tuturnya "saya selalu mengingatkan kepada anak-anak untuk selalu jangan meninggalkan shalat dan selalu ingat sama Allah dimanapun mereka berada."

Pada nilai pancasila ke-2 Kemanusiaan Yang Adil Dan Beradab di dalam keluarga bahwa orangtua adalah cerminan utama dalam melakukan prilaku yang adil terhadap anak maupun istri didalam keluarga terlebih kepada tentangga sekitar. Sebab anak akan melihat dan mencontoh bagaimana dia diperlakukan di dalam keluarga dan seberapa besar dia ikut andil dalam setiap keputusan didalam keluarga. Menurut bapak Adem tuturnya " menjadi manusia yang adil itukan berarti kita harus bisa menempatkan sesuatu pada tempatnya, memberikan sesuatu yang sesuai dengan kebutuhannya. Artinya hal yang selalu saya ajarkan dari nilai tersebut kepada anak adalah saya memberika mereka kasih sayang dengan sama rata, mengajari mereka pemahaman bahwa kakak dan adik mempunyai kebutuhan yang berbeda dan ada takaran-takaran agar kebutuhan mereka terpenuhi sesuai dengan kebutuhannya dan begitu juga kepada istri saya. kita selalu menyarankan berbuat baik kepada tetangga, sebab penolong pertama dalam keluarga kita pasti tetangga kita yang secara letak rumahnya bedekatan dengan kita". Dan ibu Uun tuturnya "Saya selalu menyayangi mereka dan tidak membedakan mereka dalam hal kasih sayang. terlebih ketika memberi uang jajan, saya selalu mengingatkan kebutuhan adik sama kakak itu berbeda"

Pada nilai pancasila ke-3 Persatuan Indonesia implementasinya didalam keluarga bahwa persatuan adalah upaya kita menjaga keluarga agar tetap rukun dan damai. Menjaga persatuan dan kesatuan didalam keluarga sangat penting dalam upaya menciptakan iklim keharmonisan terhadap anak dan orang tua. Menurut bapak Adem tuturnya " saya selalu tegas kan kepada keluarga saya bahwa kita didalam keluarga harus saling bahu-membahu, bantu-membatu dalam keadaan apapun, saling menghormati kepada yang lebih tua. Mengutamakan kepentingan keluarga dan membantu tetangga yang membutuhkan". Menurut ibu Uun " kerukunan dalam keluarga menurut saya adalah bentuk dari sebuah persatuan, karna sebagai seorang ibu saya selalu 
mengingatkan agar selalu rendah hati dan saling menyangi"

Pada nilai pancasila ke-4 Kerakyatan Yang Dipimpin Oleh Hikmat Kebijaksanaan Dalam Permusyawarahan/Perwakilan didalam keluarga adalah bahwa setiap keputusan yang di ambil dan dijalankan didalam keluarga harus di ambil dengan cara kemufakatan bersama antara anggota keluaraga. Ikut ndil dalam menentukan peraturan dirumah dan bertanggung jawab dalam melaksanakannya. Menurut bapak Adem tuturnya "saya selaku kepala rumah tangga berhak mengatur dan menentukan apa saja yang harus dilakukan didalam keluarga. Tapi karna saya tahu bahwa hal tersebut adalah keputusan yang tidak tepat, dalam menyelesaikan setiap masalah saya selalu mengumpulkan keluarga untuk mencari solusi bersama agar setiap masalah yang dihadapi dapat terselesaikan. Contohnya saya memberikan pilihan dan masukan terhadap minat pendidikan yang akan dia ambil untuk kedepannya". Kemudian menurut ibu Uun "kalau masalah ini biasanya saya lebih menyerahkan kepada kepala keluarga yaitu suami saya, dan saya hanya memberikan masukan"

Pada nilai pancasila ke-5 Keadilaan Sosial Bagi Seluruh Rakyat Indonesia bentuk pengimplementasiaanya didalam keluarga berupa keadillan menyeluruh terhadap anggota keluarga yang disepakati secara bersama dan bergotong royong serta bertanggung jawab dalam melaksanakannya. Sila ke-5 merupakan bentu keseimbangan antara hak dan kewajiban, serta memupuk sikap adil terhadap anggota keluarga. Menurut bapak Adem tuturnya " seperti yang saya katakan tadi bahwa keadilan di dalam keluarga adalah menjadi manusia yang adil berarti kita harus bisa menempatkan sesuatu pada tempatnya, memberikan sesuatu yang sesuai dengan kebutuhannya. Dalam hal sederhana saja misalnya memberika uang jajan, keadilan itu bukan berupa nominal yang sama rata, tetapi kita memberikan sesuai kebutuhan anak saja. Dan saya selalu memberika kebebasan kepada anak-anak untuk menentukan pendidikan mereka asal jangan meninggalkan ajaran agama. Kemudia menurut ibu Uun tuturnya "keadilaan ini bagi saya adalah saya menyayangi dan mengasihi mereka semuanya sama, tidak ada yang dibeda-bedakan"
Menurut Nur Khosiah dalam jurnal Studi Keislaman (2020:91-92) bahwa Ketuhanan Yang Maha Esa dari sejak nenek moyang kita terdahulu sudah percaya kepada tuhan, sila pertama inilah yang menjiwai keempat sila lainnya. Sila ke-2 Kemanusiaan Yang Adil Dan Beradab dijiwai oleh dila-sila lainnya. Negara merupakan lembaga kemanusiaan yang diadakan oleh manusia. Keadilan yang harus dicapai dalam hidup manusia bersama sama sebagai makhluk tuhan yaitu untuk mewujudkan keadilan kepada seluruh manusia dan berdampingan dalam menjalankan kehidupan. Sila ke-3 Persatuan Insonesia dijelaskan bahwa yang mendasari sila ke-3 ini adalah sila ke-1 Ketuhanan Yang Maha Esa dan ke-2 Kemansiaan Yang Adil Dan Beradab, bahwasannya manusia sebagai makhluk ciptaan Tuhan harus bisa mengimplementasikan terwujudnya suatu persatuan dalam hidup bermasyarakat, tanpa memandang status, warna kulit, keturunan, ras, suku, agama serta dapat menumbuhkan rasa cinta tanah air. Sila ke-4 Kerakyatan Yang Dipimpin Oleh Hikmat Kebijaksanaan Dalam Permusyawarahan/Perwakilan, maka sila ke-4 ini mengandung pokok kerakyatan yang semuanya ditujukan untuk rakyat. Dam permusyawaratan artinya musyawarah untuk mufakat setelah itu di adakan dan di laksanakan bersama-sama dan bergotong royong. Sila terakhir dalam pancasila adalah Keadilan Bagi Seluruh Rakyat Indonesia adalah tujuan dari ke empat sila sebelumnya yaitu, Ketuhanan Yang Maha Esa, Kemanusiaan Yang Adil Beradab, Persatuan Indonesia, Kerakyatan Yang Dipimpin Oleh Hikmat Kebijaksanaan Dalam Permusyawarahan/Perwakilan. Adapun pokok pikiranya adalah kesejahteraan dan kemakmuran bagi rakyat indonesia, kekayaan alam seluruhnya untuk kepentingan umum dan kesejahteraan bersama, serta melindungi seluruh rakyat indonesia agar dengan bebas bisa melaksanakan aktivitasnya

Pembahasan tentang nilai-nilai pancasila didalam lingkungan keluarga dijelaskan oleh Badan Pembinaan Ideologi Pancasila atau biasa kita kenal dengan BPIP, merupakan lembaga yang berada di bawah dan bertanggung jawab kepada presiden. Dijelaskan bahwa butir-butir pengamalan nilai-nilai pancasila adalah sebagai berikut : 


\section{Pengamalan sila ke-1 "Ketuhanan Yang Maha Esa"}

Sila pertama ketuhanan yang maha esa mengandung butir-butir pengamalan beserta nilai-nilai dan makna yang dapat di terapkan dalam keshidupan sehari-hari terutama didalam lingkungan keluarga. UUD 1945 menyatakan bahwa negara berdasarkan atas ketuhanan yang maha esa, serta negara menjamin kemerdekaan tiap-tiap penduduk untuk dapat memeluk agamanya masing-masing dan beribadah menurut agama dan kepercayaannya.

Negaraberperan sangat penting dalam meberikan jaminan kepada semua penduduk untuk memeluk dan beribadah sesuai agama dan kepercayaanya masing-masing. Negara berfungsi untuk dapat memperjuangkan, menjamin, membantu dan mengupayakan agar setiap masyarakatnya memiliki kebebasan untuk memeluk agamanya dan beribadah sesuai kepercayaannya (Weinata Sairin 2002). Pemerintah tidak mengatur dan mencapuri urusan agama dan kepercayaan, melainkan negara menjamin agar masyarakat dapat beribadah berjalan dengan semestinya.

Dengan demikian, sila ke-1 "Ketuhanan Yang Maha Esa" memberikan ruang yang besar untuk terwujudnya kerukunan antara umat beragama di negara Republik Indonesia.

Butir-butir pengamalan sila ke-1 yang berbunyi "Ketuhanan Yang Maha Esa" disimbolkan dengan lambang bintang yaitu :

1. Bangsa indonesia menyatakan lepercayaan dan ketakwaannya kepada Tuhan Yang Maha Esa.

2. Manusia Indonesia percaya dan takwa terhadap Tuhan Yang Maha Esa, sesuai dengan agama dan kepercayaanya masing-masing menurut dasar kemanusiaan yang adil dan beradab.

3. Mengembangkan sikap hormat dan bekerja sama antara pemeluk agama dan penganut kepercayaan yang berbedabeda terhadap Tuhan Yang Maha Esa.

4. Membina kerukunan hidup diantara sesama umat beragama dan kepercayaan terhadap Tuhan Yang Maha Esa.

5. Agama dan kepercayaan terhadap Tuhan adalah masalah yang menyangkut hubungan pribadi manusia dengan Tuhan-Nya.
6. Mengembangkan sikap saling menghormati dan kebebasan menjalakan ibada sesuai perintah agamanya

7. Tidak memaksakan suatu ajaran agama kepada orang lain.

Pengamalan butir-butir sila ke-1 dapat di terapkan dimanapun sebagai perwujudan kimitmen terhadap ajaran agama yang dipeluknya, termasuk didalam lingkungan keluarga.

1. Melakukan ibadah bersama keluarga

2. Menghormati anggota keluarga yang sedang menjalankan ibadah

3. Melaksanakan ibadah tepat waktu

4. Menjalankan hari-hari besar agama yang dipeluknya

5. Hidup rukun bersama tetangga yang berbeda agamanya

6. Tidak membeda-bedakan karena berbeda dalam kepercayaan

\section{Pengamalan sila ke-2 “Kemanusiaan Yang Adil Dan Beradab"}

Pengamalan sila ke-2 dalam kehidupan harus seraya diterapkan oleh masyarakat indonesia dimanapun mereka berada. Karna Pancasila sebagai dasar falsafah yang menjadi landasan dalam berbangsa dan bernegara. Perwujudan sila ke-2 yang dimiliki bangsa indonesia, bahwa manusia merupakan makhluk yang berbudaya, bermoral, dan beragama.

Nilai kemanusiaan tersebut menjadi 10 butir-butir pengamalan sila ke-2 pancasila, sebagai berikut :

1. Mengakui dan memperlakukan manusia sesuai dengan harkat dan martabatnya sebagai makhluk Tuhan Yang Maha Esa.

2. Mengakui persamaan derajat, persamaan hak, dan kewajiban setiap manusia tanpa membedakan SARA.

3. Mengembangkan sikap saling mencintai sesama manusia.

4. Sikap tenggang rasa dan tepa selira.

5. Sikap jangan semena-mena terhadap orang lain.

6. Menjunjung tinggi nilai-nilai kemanusiaan.

7. Gemar melakukan kegiatan kemanusiaan.

8. Berani membela kebenaran dan keadilan. 
Jurnal Edumaspul, 5 (2), Year 2021 - 402 Rizal Saputra' ${ }^{1}$, Ajat Rukajat ${ }^{2}$, Yayat Herdiana ${ }^{3}$

9. Bangsa indonesia merasa dirinya sebagai bagian dari seluruh umat manusia.

10. Sikap hormat dan bekerja sama dengan bangsa lain.

Manusia sebagai makhluk ciptaan Tuhan, harus saling menghargai tanpa pandang bulu. Hal tersebut merupakan esensi dari dari butir pertama "Mengakui dan memperlakukan manusia sesuai dengan harkat dan martabatnya sebagai makhluk Tuhan Yang Maha Esa". Maka, sila ke-2 Pancasila sedari dini diajarkan dan diterapkan di lingkungan keluarga. Bentuk pengamalan dari sila ke-2 di lingkungan keluarga adalah sebagai berikut :

1. Menyayangi kedua orang tua sepenuh hati.

2. Menghormati yang lebih tua dan menghargai yang lebih muda.

3. Berbuat baik, berbagi dan saling membantu kepada tetangga.

4. Tidak mudah menghakimi orang lain dan tidak merasa benar sendiri.

5. Memberikan empati dan kasih sayang kepada saudara dan tetangga yang membutuhkan.

\section{Pengamalan sila ke-3 "Persatuan Indonesia" dilingkungan keluarga}

Sila ke-3 dala pancasila yang berbunyi "persatuan indonesia" mengandung butir-butir pengamalan dan makna yang mendalam. Pengamalan pancasila sila ke-3 bisa diterapkan dalam kehidupan sehari-hari termasuk dirumah yang merupakan lingkungan keluarga. Sila ke-3 merupakan landasan untuk menjaga persatuan dan kesatuan bangsa indonesia. Sila ke-3 memuat tujuh butir pengamalan yaitu :

1. Mampu menempatkan persatuan, kesatuan serta kepentingan dan keselamatan bangsa dan negara sebagai keentingan bersama diatas kepentingan pribadi dan golongan

2. Sanggup dan rela berkorban untuk kepentingan bangsa dan negara apabila diperlukan

3. Rasa cinta kepada tanah air dan bangsa

4. Rasa kebanggaan berkebangsaan bertanah air indonesia

5. Memelihara dunia yang berdasarkan kemerdekaan, perdamaian abadi, dan keadilan sosial
6. Persatuan indonesia atas dasar Bhineka Tunggal lka

7. Memajukan pergaulan demi persatuan dan kesatuan bangsa.

Prinsip persatuan indonesia yang ditanamkan kepada anak didalam keluarga adalah sebagai berikut:

1. Giat belajar agar dapat membanggakan keluarga

Bahwa peran orangtua didalam pendidikan sangat berpengaruh besar dalam mengolah pikiran dan kepribadian anak. Pengajaran yang tepat sesuai kebutuhan anak, maka pendidikan yang dihasilkan akan merubah anak ketika dia mengijak peride pendidikan disekolah. Hal ini juga menjadi salah satu faktor keberhasilan anak untuk dapat membanggakan keluarga

2. Tingkatkan rasa hormat kepada anggota keluarga yang lebih tua dan menghargai anggota keluarga yang lebih muda

Keberhasilan anak dalam mengolah kepriadiannya tergantung kepada bagaimana dia pertamakali diajarkan budi pekerti didalam keluarga. Ini akan bedampak besar ketika anak sudah memasuki dunia pendidikan. Mengajarkan sopan santun, tatakrama, dan toleransi kepada anak didalam keluarga adalah sebuah kewajiban bagi orang tua agar didalam pergaulan anak dapat mengimplementasikannya dan menjalin hubungan harmonis baik kepada teman sebaya maupun kepada orang yang lebih tua

3. Membantu berbagai kegiatan dalam keluarga

Mengajarkan tanggung jawab kepada anak dalam keluarga adalah modal utama seorang anak untuk selalu berpegang teguh kepada pendiriannya.

4. Mengutamaka kepentingan bersama Kepentingan bersama adalah hajat untuk dilakukan secara bersama-sama dan untuk kemaslahatan orang banyak,

5. Selalu menjaga kerukunan dengan sesama keluarga

Keharmonisan dan saling menghargai didalam keluarga harus tanamkan dan dipupuk kepada anak sedari kecil. Sebab keluarga merupakan miatur pergaulan 
anak pertama kali dia mengenal sebuah perbedaan, baik pemikiran maupun tingkah laku. Maka dari itu yang kita tanam sedari dini kepada anak maka dia akan menuainya ketika sudah bergaul dengan masyarakat luas.

\section{Pengamalan sila ke-4 "Kerakyatan Yang Dipimpin Oleh Hikmat Kebijaksanaan Dalam Permusyawarahan/Perwakilan" dilingkungan keluarga}

Sila ke-4 yang dilambangkan dengan "Kepala Banteng" yaitu sebagai hewan sosialyang suka berkumpul dan berkelompok. Saat hewan itu berkumpul maka mereka akan menjadi kuat dan tidak bisa dikalahkan. Lambang tersebut menggambarkan bahwa bangsa indonesia yang kompak bergotong royong, berdiskusi dan bermufakat dalam melalukan segala keputusan.

Dalam pengamalannya, sila ke-4 mempunyai 10 butir pengamalan yang dikutip dari webshite Kemenhan (2014) sebagai berikut ;

1. Sebagai warga negara dan warga masyarakat, setiap manusia indonesia mempunyai kedudukan, hak dan kewajiban yang sama.

2. Tidak boleh memaksakan kehendak kepada orang lain.

3. Mengutamakan musyawarah dalam mengambil keputusan untuk kepentingan bersama.

4. Musyawarah untuk mencapai mufakat diliputi dengan semangat kekeluargaan

5. Menghormati dan menjunjung tinggi setiap keputusan yang dicapai sebagai hasil musyawarah

6. Dengan itikad baik dan rasa tanggung jawab menerima dan melaksanakan hasil.

7. Di dalam musyawarah diutamakan kepentingan bersama diatas kepentingan pribadi dan golongan

8. Musyawarah dilakukan dengan akal sehat dan sesuai dengan hati nurani yang luhur.

9. Keputusan yang diambil harus dapat dipertanggung jawabkan secara moral Kepada Tuhan Yang Maha Esa, menjunjung tinggi harkat dan martabat manusia, nilai-nilai kebenaran dan keadilan mengutamakan persatuan dan kesatuan demi kepentingan bersama
10. Memberikan kepercayaan kepada wakilwakil yang dipercayai untuk melaksanakan permusyawaratan

Pengamalan sila ke-4 dirumah atau di dalam lingkungan keluarga

Butir pengamalan musyawarah untuk mencapai mufakat dalam mencari solusi kehidupan bernegara juga diterapkan dilingkungan kecil yaitu lingkungan keluarga dirumah. Setiap individu dalam sebuah keluarga pasti memiliki kegemaran masing-masing yang bisa saja saling bertentangan. Ketika mencari keputusan dengan menghindari konflik, maka hendaknya dilakukan musyawarah yang dipimpin oleh anggota keluarga yang paling tua baik kakek ataupun ayah. Setiap anggota keluarga harus bisa menghormati pendapat yang lebih tua dan sebaliknya yang tua menghargai pendapat yang lebih muda agar terciptanya kelancaran dalam bermusyawarah.

Dengan kata lain, pengamalam pancasila ke-4 dikehidupan keluarga adalah sebagai berikut :

1. Setiap masalah keluarga diselesaikan melalui musyawarah untuk mencapai kata sepakat.

2. Berjiwa besar untuk menerima dan mempertimbangkan pendapat sesama anggota keluarga

3. Seriap anggota keluarga bertanggung jawab melaksanakan hasil keputusan

\section{Pengamalan sila ke-5 "Keadilan Sosial Bagi Seluruh Rakyat Indonesia"}

Pancasila merupakan dasar negara indonesia segaligus menjadi pedoman dalam kehidupan berbangsa dan bernegara dengan nilai-nilai luhur yang diterapkan didalamnya. Pengamalan pancasila hendaknya diajarkan sejakdini kepada anak-anak termasuk sila ke-5 didalam keluarga sebagai pendidikan pertama anak.

Yudi Latif dalam Negara Parpurna (2011) menyatakan bahwa keadilan sosial bagi seluruh rakyat indonesia merupakan perwujudan yang paling konkret dari prinsip-primsip pancasila. Prinsip keadilan sosial adalah inti dari moral ketuhanan, landasan pokok berprikemanusiaan, simbol tali persatuan dan matra kedaulatan rakyat. Dengan kata lain keadilan sosial merupakan cerminan asas imperatif dari prinsipprinsip pancasila. 
Notonegoro (1975:141) dalam bukunya menuliskan bahwa keadilan bagi seluruh rakyat indonesiadijiwai dan diliputi oleh nilai-nilai ketuhanan, prikemanusiaan, persatuan, dan kebijaksanaan.

Butir-butir pengamalan sila ke-5 yakni keadilan sosial bagi seluruh rakyat indonesia diatur dalam Ketetapan MPR No.1/MPR/2003 sebagai berikut

1. Mengembangkan perbuatan yang luhur, yang mencerminkansikap dan suasana kekeluargaan dan gotong royong.

2. Mengembangkan sikap adil terhadap sesama.

3. Menjaga keseimbangan antara hak dan kewajiban.

4. Menghormati hak orang lain.

5. Memberi pertolongan kepada orang lain agar dapat berdiri sendiri

6. Tidak menggunakan hak milik untuk melakukan usaha yang bersifat pemerasan terhadap orang lain.

7. Tidak menggunakan hak milik untuk halhal yang bersifat pemborosan dan gaya hidup mewah.

8. Tidak menggunakan hak milik untuk bmerugikan kepentingan umum.

9. Suka bekerja keras dan menghargai hasil karya orang lain yang bermanfaat bagi kemajuan bersama.

10. Melakukan kegiatan untuk kemajuan dan keadilan sosial yang merata.

Bentuk pengamalan sila ke-5 dalam lingkungan keluarga adalah sebagai berikut :

1. Bergotong royong dalam menyelesaikan suatu pekerjaan dalam keluarga.

2. Bersama-sama menyelesaikan setiap ada suatu permasalahan dalam keluarga.

3. Saling membantu sesama keluarga yang mendapatkan kesulitan

4. Berprilaku adil dalam pembagian hak dan kewajiban

5. Tidak membeda-bedakan satu sama lain dalam keluarga.

\section{KESIMPULAN}

Keluarga adalah pendidikan pertama bagi seorang anak untuk belajar, berkembang dan memahami lingkungan nya. Keluarga yang berhasil dalam menanamkan karakter kepada anaknya terlebih penanaman karakter yang terdapat pada nilai-nilai pancasila adalah keluarga yang hebar, yang akan menjadikan anaknya sebagai manusia yang mempunyai moral sosial dan cinta tanah airnya.

Pada nilai pancasila ke-1 Ketuhanan Yang Maha Esa didalam keluarga menjelaskan bahwa dalam agama Islam bahwa Ketuhanan Yang Maha Esa adalah bentuk keimanan kita yang harus senantiasa kita pegang dan kita ajarkan kepada keturunan kita, karna tauhid inilah yang akan menjadi pondasi serta landasan kita dalam berkehidupan terlebih di dalam keluargadan betetangga yang berbeda agamanya.

Pada nilai pancasila ke-2 Kemanusiaan Yang Adil Dan Beradab di dalam keluarga bahwa orangtua adalah cerminan utama dalam melakukan prilaku yang adil terhadap anak maupun istri didalam keluarga terlebih kepada tentangga sekitar. Sebab anak akan melihat dan mencontoh bagaimana dia diperlakukan di dalam keluarga dan seberapa besar dia ikut andil dalam setiap keputusan didalam keluarga.

Pada nilai pancasila ke-3 Persatuan Indonesia implementasinya didalam keluarga bahwa persatuan adalah upaya kita menjaga keluarga agar tetap rukun dan damai. Menjaga persatuan dan kesatuan didalam keluarga sangat penting dalam upaya menciptakan iklim keharmonisan terhadap anak dan orang tua.

Pada nilai pancasila ke-4 Kerakyatan Yang Dipimpin Oleh Hikmat Kebijaksanaan Dalam Permusyawarahan/Perwakilan didalam keluarga adalah bahwa setiap keputusan yang di ambil dan dijalankan didalam keluarga harus di ambil dengan cara kemufakatan bersama antara anggota keluaraga. Ikut ndil dalam menentukan peraturan dirumah dan bertanggung jawab dalam melaksanakannya.

Pada nilai pancasila ke-5 Keadilaan Sosial Bagi Seluruh Rakyat Indonesia bentuk pengimplementasiaanya didalam keluarga berupa keadillan menyeluruh terhadap anggota keluarga yang disepakati secara bersama dan bergotong royong serta bertanggung jawab dalam melaksanakannya. Sila ke-5 merupakan bentu keseimbangan antara hak dan kewajiban, serta memupuk sikap adil terhadap anggota keluarga 
Jurnal Edumaspul, 5 (2), Year 2021 - 405 Rizal Saputra ${ }^{1}$, Ajat Rukajat ${ }^{2}$, Yayat Herdiana ${ }^{3}$

\section{DAFTAR PUSTAKA}

Budimansyah, Dasim. (2011). PEMBINAAN KARAKTER GENERASI MUDA. Bandung : CV. Dua Usaha Muda.

Djumali. (2018) Pembentukan Karakter Dalam Proses Pembelajaran. Universitas Muhammadiyah Surakarta : Modul Seminar Pendidikan. 2018.

http://bpip.go.id/bpip/berita/sosial/butir-butirpsncasila.html di akses 28 juli 2021

http://www.kemhan.go.id/renhan/2014/20/45butir-pedoman-penghayatan-dan-pengamalanpancasila.html di akses 28 juli 2021 https://id.m.wikipedia.org/wiki/Pancasila diakses pada 28 juli 2021

Juliani, Sri. (2010). "Implemenpendidikan Karakter Disekolah Melalui Penguatan Pelaksanaan Kurikulum. Jurnal pendidikan dan kebudayaan.

Kaelan. (2010). Pendidikan Pancasila "Edisi Reformasi". Yogyakarta : Paradigma.

Ketetapan MPR RI Nomor 1/MPR/2003
Khosiah, Nur. (2010). Implementasi Nilai-Ni;Ai Pancasila Peserta Didik Di Madrasah Ibtidaiyah Mambail Falah Tongas-Probolinggo. Jurnal AlInsyiroh : Jurnal Studi Keislaman. Vol. 6, No. 1, Maret.

Latif, Yudi. (2011). Negara paripurna "Historitas, Rasionalitas, dam Aktualitas Pancasila". Jakarta : PT. Gramedia Pustaka Utama.

Makmudah, Siti. (2018). Penguatan Peran Keluarga Dalam Pendidikan Anak. Jurnal Perempuan Dan Anak. Vol. 2. No 2. Desember. Nazir, M. (1998). Metode Penelitian. Ghalia Indonesia : Jakarta.

Notonegoro. (1997). Pancasila Dasar Filsafat Negara Republik Indonesia. Jakarta : CV. Pantja. Rahman S, Hibana. (2010). Pendidikan Anak Usia Dini. Jakarta : Rineka Cipta.

Sugiono. (2013). Metode Penelitian kuantitatif, kualitatif dan R\&D. Bandung : Alfabeta.

UU No. 20 Tahun 2003 Tentang Sistem Pendidikan Nasional 